\title{
ARRANJOS INSTITUCIONAIS NO PROCESSO CONSTITUINTE DE 1987-1988: UM ESTUDO DE CASO A PARTIR DA COMPETÊNCIA CONGRESSUAL PARA SUSTAR ATOS NORMATIVOS DO PODER EXECUTIVO
}

\author{
INSTITUTIONAL ARRANGEMENTS IN THE CONSTITUTIONAL PROCESS OF 1987- \\ 1988: A CASE STUDY FROM THE CONGRESS COMPETENCE TO SUPPRESS \\ NORMATIVE ACTS OF THE EXECUTIVE BRANCH
}

\begin{abstract}
Cássio Luís Casagrande
Professor Adjunto de Direito Constitucional da Universidade Federal Fluminense (Niterói/RJ). Docente Permanente do Programa de Pós-Graduação em Direito Constitucional PPGDC/UFF (Niterói/RJ). Doutor em Ciência Política pelo Instituto Universitário de Pesquisas do Rio de Janeiro (IUPERJ). Mestre em Relações Internacionais pela Pontifícia Universidade Católica do Rio de Janeiro (PUC-Rio).

E-mail: cassio_casagrande@hotmail.com

Dalton Robert Tibúrcio

Mestre pelo Programa de Pós-Graduação em Direito Constitucional da Universidade Federal FluminenseUFF. Especialista em Advocacia Pública pela Universidade do Estado do Rio de Janeiro-UERJ.

E-mail: daltonrobert2014@gmail.com
\end{abstract}

Recebido em: 02/07/2018

Aprovado em: 04/10/2018

\begin{abstract}
RESUMO: O presente artigo tem por objeto o estudo de caso sobre a introdução da competência exclusiva do Congresso Nacional para sustar os atos normativos do Poder Executivo que exorbitem do poder regulamentar ou dos limites de delegação legislativa (art. 49, V, da Constituição). Investiga-se a relação dessa competência com o projeto parlamentarista, que dirigiu grande parte do processo constituinte sobre a organização dos Poderes. A partir do levantamento dos registros documentais dos trabalhos constituintes e da revisão doutrinária, retrata-se o arranjo institucional que marcou o processo decisório da Assembleia Nacional Constituinte. Sustenta-se que o sistema de Governo concretamente adotado pela Constituição não deve ser avaliado a partir de uma visão idealizada do presidencialismo. A hipótese a ser verificada é a de que a competência em questão guarda relativa independência com o projeto parlamentarista.
\end{abstract}

Palavras-Chave: Presidencialismo. Assembleia Nacional Constituinte. Legislativo. Executivo.

ABSTRATC: The purpose of this article is to study the case of the introduction of the National Congress exclusive competence to suppress normative acts of the Executive Branch that exceed the regulatory function or the limits of the legislative delegation (Article 49, V, of the Constitution). The article investigates the relation of that competence with the parliamentary project, which directed much of the constituent process on the organization of the Branches. From the survey of the documentary records of the constituent works and doctrinal revision, the institutional arrangement that marked the decision-making process of the National Constituent Assembly is portrayed. It is maintained that the government system concretely adopted by the Constitution should not be evaluated from an idealized view of presidentialism. The hypothesis to be verified is that the competence in question retains relative independence with the parliamentary project.

Keywords: Presidentialism. National Constituent Assembly. Legislative. Executive. 
SUMÁRIO: Introdução; 1. O caráter congressual da Assembleia Nacional Constituinte; 2. O anteprojeto da Subcomissão do Poder Legislativo; 3. A proposta do deputado constituinte Victor Fontana; 4. O anteprojeto da Comissão da Organização dos Poderes e Sistema de Governo; 5. O projeto da Comissão de Sistematização; 6. A rebelião do Centrão; 7. A votação em primeiro turno; 8. A emenda presidencialista; 9. O segundo turno de votações e a redação final; 10 . A tentativa de introdução do controle de atos normativos do Poder Judiciário; 11. Análise dos trabalhos constituintes; Conclusão; Referências.

SUMMARY: Introduction; 1 . The congressional character of the National Constituent Assembly; 2. The preliminary draft of the Subcommittee of the Legislative Branch; 3. The proposal of constituent Representative Victor Fontana; 4. The preliminary draft of the Commission for Branches Organization and System of Government; 5. The project of the Systematization Commission; 6. The rebellion of the "Centrão"; 7. First-round voting; 8. The presidential amendment; 9. The second round of voting and the final draft; 10 . The attempt to introduce the control of normative acts of the Judiciary Branch; 11. Analysis of the constituent works; Conclusion; References.

\section{INTRODUÇÃO}

Os trabalhos da Assembleia Nacional Constituinte (ANC) de 1987-1988 produziram uma inovação institucional relevante no controle congressual sobre o Executivo: a competência exclusiva do Congresso Nacional de sustar os atos normativos do Poder Executivo que exorbitem do poder regulamentar ou dos limites de delegação legislativa (art. 49, V, da Constituição).

A Constituição de 1934 atribuía ao Senado Federal a competência para examinar, em confronto com as respectivas leis, os regulamentos expedidos pelo Poder Executivo e suspender a execução dos dispositivos ilegais e para propor ao Poder Executivo, mediante reclamação fundamentada dos interessados, a revogação de atos das autoridades administrativas, quando praticados contra lei ou eivados de abuso de poder (Constituição Federal de 1934, art. 91, II e III).

Valadão ressalta que esse precedente histórico deve ser interpretado com ressalvas, tendo em vista que "o Senado Federal, na Carta de 1934, era diferente, não se tratava de casa legislativa em sua acepção plena, mas estava mais próximo de ser um órgão de coordenação dos poderes federais" (VALADÃO, 2002, p. 289). Poletti (2001, p. 49-50), por sua vez, destaca que a competência prevista no art. 91, II, da Constituição de 1934 era um resquício do anteprojeto de Constituição, que tinha a intenção de extinguir o bicameralismo e transformar o Senado em um Conselho Supremo. A competência do Conselho substitutivo do Senado era prevista no art. 68 do Anteprojeto de Constituição:

O Conselho Supremo será órgão consultivo e deliberativo, com funções políticas e administrativas, manterá a continuidade administrativa nacional; auxiliará, com o seu saber e experiência, os órgãos do Governo e os Poderes Públicos, por meio de pareceres, mediante consulta; deliberará e resolverá sobre os assuntos de sua competência fixados nesta Constituição. (POLETTI, 2001, p. 31)

A Constituição de 1934 acabou acolhendo uma solução híbrida e manteve o bicameralismo, mas incumbiu ao Senado um papel de "promover a coordenação dos poderes federais entre si, manter a continuidade administrativa, velar pela Constituição, colaborar na feitura de leis e praticar os demais atos de sua competência" (art. 88 da Constituição de 1934).

A anterior previsão - que não se repetiu nas Constituições de 1937, 1946 e 1967 -, portanto, não é equivalente à norma do art. 49, V, da Constituição de 1988, tendo em vista a 
diferença no desenho institucional do papel do órgão controlador. A inovação da Constituição de 1988 está na introdução de um mecanismo de controle político congressual que permite a intromissão direta do Legislativo no Executivo, remodelando os pesos e contrapesos da separação de poderes.

Ferraz (1994, p. 213-215), ao encerrar seu estudo sobre o poder congressual de sustar atos normativos do Poder Executivo, concluiu que a competência em questão seria uma indevida reminiscência do projeto parlamentarista, que havia permeado boa parte dos trabalhos constituintes. Assim, a autora recomendou que a competência fosse revogada, por ocasião da revisão constitucional prevista no art. $3^{\circ}$ do ADCT. Concluiu a autora;

Frente à separação de poderes, inscrita como princípio fundamental e intocável e concretizada no sistema presidencialista de governo na Constituição de 1988, a sustação congressual de atos normativos regulamentares constitui figura aberrante, que não se ajusta aos lindes do controle político para o qual o Poder Legislativo é naturalmente vocacionado. (FERRAZ, 1994, p. 213)

Note-se que a autora parece ter revisto seu posicionamento, uma vez que posteriormente afirmou, sobre a competência do art. 49, V, da Constituição: "Trata-se de função que fortalece o Poder Legislativo no quadro estrutural dos poderes e que se bem utilizada poderá até constituir ferramenta relevante para efetivo controle do Poder Executivo" (FERRAZ, 2013, p. 1030-1031).

De toda forma, permanece a questão que merece ser investigada pela pesquisa empírica: a norma do art. 49, V, da Constituição é fruto de uma reminiscência no texto constitucional do projeto parlamentarista? Haveria, nessa competência, uma incompatibilidade intrínseca com a separação de poderes ditada pelo sistema presidencialista de Governo?

A hipótese sustentada nesse artigo é a de que havia na Constituinte uma clara tentativa de fornecer instrumentos para incrementar o poder do Legislativo de fiscalizar o Executivo, que transcendia o projeto parlamentarista. Dessa forma, a ideia de que o instrumento de controle previsto no art. 49, V, da Constituição seria um elemento parlamentarista parte de uma compreensão idealizada do sistema de governo.

O Parlamentarismo possui elementos institucionais característicos, como a responsabilização política do Chefe de Governo e a possibilidade de dissolução do parlamento, como destacam Iensue e Sgarbossa (2016, p. 264-285). No entanto, como ressaltam Shugart e Carey (1992), regimes onde há a eleição de um Presidente em separado do Parlamento característica nuclear do presidencialismo - podem assumir uma variedade de desenhos institucionais, que os aproximam ou os afastam dos regimes parlamentaristas. Portanto, ao invés de presidencialismo versus parlamentarismo, parece mais adequado pensar em formas de presidencialismos, que podem ser mais próximas ou mais afastadas do modelo parlamentarista.

A partir desse panorama, o presente artigo se propõe a analisar como se deu a inclusão na Constituição da competência exclusiva do Congresso Nacional para controlar os atos normativos do Poder Executivo exorbitantes do poder regulamentar e dos limites da delegação legislativa. A metodologia utilizada é a investigação qualitativa por meio de estudo de caso, em que se busca uma compreensão profunda de uma unidade assumida como um todo - o processo de inclusão da competência exclusiva do Congresso Nacional prevista no art. 49, V da Constituição -, com a finalidade revelar as complexidades dessa totalidade e entender um problema do qual o caso é uma representação relevante (CRESWELL, 2014, p. 86-90; CHIZZOTTI, 2017, p. 125-128). Por meio desse estudo de caso, retratar-se-á o arranjo institucional que marcou o processo decisório da Assembleia Nacional Constituinte (ANC) de 1987-1988.

Para possibilitar esse olhar retrospectivo, utilizam-se como fontes primárias os documentos sobre os trabalhos da ANC disponibilizados nos sítios na rede mundial de computadores da Câmara dos Deputados e do Senado Federal (BRASIL, 2017a; BRASIL, 2017b). 
Além da análise documental direta, o artigo utiliza-se da revisão doutrinária e jurisprudencial para a compreensão do objeto de pesquisa.

\section{O CARÁTER CONGRESSUAL DA ASSEMBLEIA NACIONAL CONSTITUINTE}

A reconstrução das atividades constituintes deve ser feita a partir do seu contexto. Para tanto, convém destacar, como chave interpretativa do processo constituinte, o caráter congressual da ANC, que se manifesta em dois aspectos: (i) na composição dos seus membros; e (ii) nos procedimentos adotados para a elaboração e a votação do projeto de Constituição.

A composição da ANC decorre da decisão, materializada no seu ato convocatório - a Emenda Constitucional $n^{\circ} 26$, de 27 de novembro de 1985 -, de reunir o Congresso Nacional em Assembleia Nacional Constituinte, ao invés de convocar-se uma Constituinte exclusiva. Essa opção trouxe implicações tanto para a legitimidade dos seus membros quanto para a soberania do colegiado.

A convocação da Constituinte se insere em um processo histórico de transição da ditadura militar para a redemocratização, que teve seu ponto de maior expressão popular no movimento pela aprovação da Emenda Constitucional para possibilitar a eleição direta para Presidente da República, nos anos de 1983 e 1984. Por outro lado, a eleição de representantes para o Congresso Nacional em 1986 atribuiu legitimidade popular aos constituintes. No entanto, 23 senadores eleitos antes do ato convocatório permaneceriam no Congresso que se reuniria em Assembleia Constituinte, o que fazia suscitar questionamentos sobre a legitimidade desses integrantes da ANC. Esse foi um tema controvertido já na abertura dos trabalhos. Decidindo questão preliminar à eleição da Presidência, 394 integrantes da ANC confirmaram o mandato constituinte desses 23 senadores, apontam Souza Neto e Sarmento (2013, p. 161).

Além da questão da legitimidade dos seus integrantes, o caráter congressual da ANC, quanto à sua composição, trazia subliminarmente a discussão sobre a sua soberania, questão política e jurídica tormentosa que a acompanhou por todo o seu percurso. Após uma intensa discussão inicial entre os defensores da possibilidade de que a ANC, com base em sua soberania, alterasse o ordenamento jurídico em vigor e aqueles que defendiam que a soberania da ANC dizia respeito apenas à elaboração do documento constitucional, o Regimento Interno da ANC acabou acolhendo uma versão meramente reativa da soberania, ao estipular que a ANC poderia defender sua soberania, por meio de "projetos de decisão", editados para sobrestar medidas que pudessem ameaçar os trabalhos e as decisões soberanas da ANC (art. 59, § $7^{\circ}$ da Resolução no 2, de 1987). Embora a ANC não tenha editado nenhum "projeto de decisão", a defesa de sua soberania teve ao menos dois momentos políticos marcantes. O primeiro ocorreu um ano após a instauração do ANC, quando o Relator Geral, o deputado constituinte Bernardo Cabral, do PMDB do Amazonas, em resposta aos questionamentos alimentados pelo debate sobre a fixação do prazo do mandato do Presidente José Sarney, publicou artigo defendendo explícita e publicamente a soberania da Constituinte (CABRAL, 1988). O segundo evento ocorreu quando o Presidente da ANC, o deputado constituinte Ulysses Guimarães, do PMDB de São Paulo, após a votação em primeiro turno do projeto de Constituição, pronunciou, em 28 de julho de 1988, contundente discurso em defesa da soberania da Constituinte, para rechaçar a tentativa explícita de influência externa do Presidente Sarney sobre os seus rumos (GUIMARÃES, 1988, p. 12150-12151; SOUZA NETO; SARMENTO, 2013, p. 162).

O segundo aspecto do caráter congressual da ANC, de maior relevância para os propósitos do presente artigo, levanta questões sobre como as regras do funcionamento dos trabalhos, enquanto arranjos institucionais, influenciaram nos resultados alcançados, por limitarem as opções dos atores do processo político, como ressalta Pilatti (2006). A discussão sobre a soberania da ANC canalizou muito dos debates sobre a elaboração do Regimento Interno, ofuscando a atenção da maioria conservadora sobre as decisões quanto aos ritos a serem observados. 
Assim, elementos procedimentais, tais como a estrutura descentralizada dos trabalhos, a extensão dos temas a serem abordados e a atuação dos líderes de bancada, favoreceram a formação de uma agenda progressista. Pilatti (2016) investiga as possíveis explicações para o relativo êxito do bloco minoritário em introduzir a agenda progressista em uma Assembleia constituinte majoritariamente conservadora. $\mathrm{O}$ autor sustenta a hipótese de que esse êxito se relaciona à formação de coalizões ad hoc entre os grupos minoritários progressistas e dissidentes do bloco majoritário, viabilizadas pelas condições institucionais e pela estrutura dos procedimentos constituintes.

Note-se que a ANC, atendendo a seu ato convocatório, funcionou de maneira unicameral, pelo sistema de "um constituinte um voto", o que relativizou o peso da esmagadora maioria conservadora do Senado na ANC. Dessa forma, embora se utilize, nesse artigo, a expressão "deputado constituinte" e "senador constituinte", ao invés da expressão genérica "constituinte", tendo em vista o caráter congressual da $\mathrm{ANC}$, com isso não se quer induzir o reconhecimento de qualquer diferença qualitativa de voto entre os representantes.

O caráter unicameral da ANC e o quórum de maioria absoluta de seus membros em votação em dois turnos eram os únicos aspectos procedimentais fixados no ato convocatório (art. $1^{\circ}$ e art. $3^{\circ}$ da $E C n^{\circ} 26$, de 1985). Os trabalhos constituintes foram definidos não só pelas regras formais do Regimento Interno, mas também por regras informais, baseados no cotidiano do Congresso Nacional. A eleição do deputado constituinte Ulysses Guimarães, como Presidente da ANC, que também exercia o cargo de Presidente da Câmara dos deputados e o funcionamento concomitante da ANC com o Congresso Nacional contribuíram para que a ANC adotasse modos de agir típicos da prática parlamentar ordinária, muito embora estivesse lidando com um processo extraordinário de elaboração de uma Constituição.

Um exemplo da incorporação de práticas do processo ordinário no funcionamento da ANC foi o reconhecimento do papel das lideranças de bancadas partidárias, com prerrogativas de manifestação e orientação de voto, como ressalta Pilatti (2016, p. 15, 25 e 312). Também merece destaque a esdrúxula atuação do líder do governo no Congresso Nacional, o deputado constituinte Carlos Sant'anna, do PMDB da Bahia, na explícita defesa dos interesses do Governo Sarney nos trabalhos da ANC, especialmente em pontos sensíveis como o sistema de Governo e a duração do mandato presidencial (BRASIL, 1988f, p. 8737 e 8770; BRASIL, 1988g, p. 11023-11024).

A necessidade de dar-se um projeto de Constituição, em razão da inexistência de um textobase a ser analisado, ditou a organização das atividades constituintes. Paulo Bonavides e Paes de Andrade ressaltam que a forma integrativa de funcionamento da ANC, por meio das comissões e subcomissões, buscava evitar a perigosa ociosidade dos constituintes, enquanto aguardavam a elaboração do Projeto de Constituição, à semelhança do ocorrido na Constituinte de 1946. Como se analisará mais adiante, esse intento não foi inteiramente alcançado, uma vez que o movimento de reforma do Regimento Interno, que eclodiu às vésperas da votação do Projeto de Constituição em Plenário, teve como uma de suas motivações a insatisfação da parcela dos constituintes que se sentiam alijados do processo decisório sobre o Projeto de Constituição, como esclarecem Bonavides e Andrade (2008, p. 458-464).

Uma característica marcante dos trabalhos foi a descentralização na produção do projeto de Constituição. O Regimento Interno da ANC, aprovado por meio da Resolução no 2, de 25 de março de 1987, estipulou que 8 Comissões temáticas, subdivididas em 24 Subcomissões, elaborariam o projeto de Constituição, e a Comissão de Sistematização reuniria as partes em um texto compilado (BRASIL, 1987k).

Para manter a atenção na competência exclusiva do Congresso Nacional para controlar os atos normativos do Poder Executivo exorbitantes do poder regulamentar e dos limites da delegação legislativa, observe-se que a Comissão da Organização dos Poderes e Sistema de Governo era integrada por três Subcomissões: a Subcomissão do Poder Legislativo, a Subcomissão do Poder Executivo e a Subcomissão do Poder Judiciário e do Ministério Público. 


\section{O ANTEPROJETO DA SUBCOMISSÃO DO PODER LEGISLATIVO}

O relatório do deputado constituinte José Jorge, do PFL de Pernambuco, ao dar conhecimento da versão inicial do Anteprojeto da Subcomissão do Poder Legislativo ao Presidente da Subcomissão e aos demais constituintes deixava claro os objetivos do Anteprojeto: combater a hipertrofia do Executivo, devolver as prerrogativas do Parlamento e dotá-lo de meios eficazes para exercê-las, especialmente pela descentralização interna dos trabalhos legislativos, com a delegação de competências às Comissões temporárias e permanentes do Congresso Nacional e de suas Casas (Comissões Legislativas). Por outro lado, a premissa parlamentarista era outro dado essencial dos trabalhos da Subcomissão do Poder Legislativo, assim como dos trabalhos da Subcomissão do Poder Executivo. A Constituinte era vista como uma oportunidade sem paralelo na história republicana de introduzir um sistema de governo que se acreditava capaz de produzir maior estabilidade à máquina governamental: o sistema parlamentarista misto (BRASIL, 1987b, p. 2-17).

$\mathrm{Na}$ esteira da recuperação das prerrogativas do Parlamento, a versão inicial do Anteprojeto do relator da Subcomissão do Poder Legislativo previa a competência exclusiva - isto é, independente da sanção presidencial - do Congresso Nacional para fiscalizar e controlar, conjuntamente ou através de qualquer das Casas, os atos do Poder Executivo, inclusive os da administração indireta (art. 5, IX, do Anteprojeto da Subcomissão) (BRASIL, 1987b, p. 21).

A fiscalização e o controle dos atos do Poder Executivo eram viabilizados por vários mecanismos: a necessidade de aprovação prévia pelo Senado Federal para o exercício de determinados cargos no Poder Executivo ${ }^{1}$; o poder impediente, pelo qual a Câmara dos deputados poderia impedir, por meio de moção ao Presidente da República, que um cidadão continuasse a ocupar um determinado cargo no Poder Executivo; pela possibilidade de instauração de Comissões de Inquérito; pelo poder de qualquer das Casas do Congresso ou de suas Comissões de convocar Ministros de Estado ou de lhes encaminhar ou a qualquer outra autoridade requerimentos de informação e ainda de receberem petições e reclamações dos cidadãos contra atos ou omissões das autoridades públicas; por meio da fiscalização financeira e orçamentária, pela qual se previa a possibilidade de as Comissões do Congresso solicitarem a atuação do Tribunal de Contas da União; e pelo dever das Comissões Legislativas de zelar pela regulamentação das leis. Sobre esse último mecanismo de controle, que já apontava para a preocupação com os limites do poder regulamentar, observe-se a fundamentação apresentada pelo Relator do Anteprojeto na Subcomissão do Poder Legislativo:

Visando atender à necessidade imperiosa de fortalecimento do papel das comissões, e em
consonância com o princípio de interrelacionamento próprio da ação integrada,
independente e harmônica dos Poderes, objetiva-se dotar a comissão de atribuições para,
junto ao Poder Executivo, acompanhar a elaboração dos atos de regulamentação das leis.
Não é raro suceder que a disposição reguladora desatenda a vontade do legislador expressa
no texto legal, acarretando distorções na sua interpretação e aplicação. Cabe, pois, ao
Poder ao qual compete, por excelência, a elaboração e aprovação da lei, zelar pela
completa compatibilização entre o seu texto, as finalidades e a norma que a regulamenta.
(BRASIL, 1987b, p. 10)

Os instrumentos institucionais de funcionamento do sistema parlamentarista previstos no Anteprojeto da Subcomissão do Poder Legislativo eram a competência da Câmara para aprovar a indicação e a moção de censura do Primeiro-Ministro e para conceder-lhe o voto de confiança, a interação entre as Comissões Legislativas e o Poder Executivo e a possibilidade de dissolução da

\footnotetext{
${ }^{1}$ O Anteprojeto inicial previa a necessidade de aprovação pelo Senado dos cargos de Presidente do Banco Central, do Procurador Geral da República e do Presidente do Instituto Brasileiro de Geografia Estatística. A inclusão do Presidente do IBGE nessa lista refletia a preocupação com a autonomia da autoridade responsável por mensurar os índices de inflação.
}

Revista de Direito Brasileira | São Paulo, SP | v. 21 | n. 8 | p. 43-61 |Set./Dez. 2018 
Câmara dos Deputados após o terceiro voto de desconfiança. O princípio da separação de poderes, portanto, assumia contornos próprios, a ponto de o relator ter preferido utilizar a expressão "princípio de interrelacionamento próprio da ação integrada, independente e harmônica dos Poderes", em seu relatório acima transcrito. Ao invés de Poderes separados, se previa a efetiva colaboração entre o Parlamento e o Executivo na constituição e condução do Governo. Assim, o governo seria exercido pelos Ministros, pelo Primeiro-Ministro e pela Câmara dos deputados. No entanto, o detalhamento dessa dinâmica de cooperação e corresponsabilidade entre os Poderes estava a cargo de outro centro deliberativo e decisório da ANC: a Subcomissão do Poder Executivo.

\section{A PROPOSTA DO DEPUTADO CONSTITUINTE VICTOR FONTANA}

$\mathrm{Na}$ fase de emendas ao Anteprojeto do relator da Subcomissão do Poder Legislativo, o deputado constituinte Victor Fontana, do PFL de Santa Catarina, apresentou, em 18 de maio de 1987, emenda para propor que dentre as competências do Senado fosse incluída a de "suspender, total ou parcialmente, a vigência de atos normativos da Administração Pública Federal, direta ou indireta, que exorbitem do poder de regulamentar ou dos limites da delegação legislativa" (BRASIL, 1987c, p. 335). Em razão do não acolhimento da emenda pela Subcomissão e pelo primeiro Substitutivo do relator da Comissão da Organização dos Poderes e Sistemas de Governo, o deputado constituinte Victor Fontana reapresentou a emenda perante a Comissão da Organização dos Poderes e Sistema de Governo em 09 de junho de 1987 (BRASIL, 1987d, p. 14). Eis a motivação das emendas do Deputado constituinte Victor Fontana:

O chamado VETO LEGISLATIVO tem como principal objetivo a salvaguarda do princípio da legalidade.

São comuns as práticas de administradores que, a título de regulamentar normas legais, legislam agredindo-as. Praticam atos sem condições de eficácia ou sustentação jurídica.

Neste caso, muito mais rapidamente e com efeito imediato e aplicação geral, pode o Senado Federal, através de resolução, suspender a vigência da norma, sem se precisar usar do recurso judicial.

A ação encontra respaldo na própria função fiscalizadora do Poder Legislativo, que sempre merece aprimorada [sic], ao lado de abrir aos representados a oportunidade de colaborar no cumprimento das leis, denunciando aos seus representantes as suas transgressões. (BRASIL, 1987d, p. 14)

O deputado constituinte Victor Fontana já havia exercido mandato parlamentar pela Arena na Legislatura de 1979-1983 e havia sido vice-governador de Santa Catarina pelo PDS no período de 1983-1987. Além disso, havia exercido atividades profissionais privadas e cargos públicos, entre 1975 a 1978, como Assessor do Secretário da Agricultura de São Paulo, Assessor do Prefeito Municipal de São Paulo e Secretário de Agricultura e Abastecimento de Santa Catarina (BRASIL, 2018a). Era, portanto, um agente público com experiência tanto no Legislativo quanto no Executivo. Essa caraterística da trajetória política do deputado constituinte Victor Fontana pode explicar a sua preocupação em dotar o Legislativo de um instrumento efetivo de controle da função regulamentar e do respeito pelo Executivo dos limites da delegação legislativa.

A Comissão da Organização dos Poderes e Sistema de Governo da ANC, por meio do relatório do deputado constituinte Egídio Ferreira Lima, do PMDB de Pernambuco, após as emendas ao primeiro substitutivo do relator da Comissão, incorporou, em 15 de junho de 1987, ao Anteprojeto da Comissão, no art. $5^{\circ}$, XII, a competência exclusiva do Congresso Nacional para sustar os atos normativos do Poder Executivo que exorbitem do poder regulamentar ou dos limites de delegação legislativa.

Não se sabe a motivação para o acolhimento parcial da emenda apresentada, uma vez que não se localizou nos documentos dos trabalhos constituintes a cópia do Parecer às emendas ao Substitutivo do relator da Comissão da Organização dos Poderes e Sistema de Governo da 
Assembleia Nacional Constituinte e do articulado que incorporou as emendas no Anteprojeto da referida Comissão da Organização dos Poderes e Sistema de Governo da Assembleia Nacional Constituinte, em especial o articulado que apreciou a emenda do deputado constituinte Victor Fontana apresentada à Comissão da Organização dos Poderes e Sistema de Governo em 09 de junho de 1987.

\section{O ANTEPROJETO DA COMISSÃO DA ORGANIZAÇÃO DOS PODERES E SISTEMA DE GOVERNO}

O Anteprojeto da Comissão da Organização dos Poderes e Sistema de Governo, no tocante às prerrogativas do Poder Legislativo, manteve a previsão da competência privativa do Congresso para fiscalizar e controlar, conjuntamente ou através de qualquer das Casas, os atos do Executivo, inclusive os da administração indireta e previu a competência para regulamentar as leis, quando da omissão do Executivo (art. $5^{\circ}$, IX e XI). Manteve, também, o poder de cada Casa do Congresso de convocar o Primeiro-Ministro e os Ministros de Estado para prestarem informações (art. $6^{\circ}$, caput), e transferiu para a Mesa a competência para encaminhar os pedidos de informações a qualquer autoridade, sobre fatos relacionado com matéria legislativa ou sujeita à fiscalização do Congresso Nacional (art. $7^{\circ}$, II). Modificou o poder impediente para a recomendação de afastamento de detentor de cargo ou função de confiança no Governo Federal (art. $9^{\circ}$, VI) e ampliou o poder do Senado de aprovar previamente os ocupantes de determinados cargos, além de outros que a lei determinar (art. 10, III). Quanto aos mecanismos parlamentaristas, o Anteprojeto manteve as competências da Câmara previstas no Anteprojeto da Subcomissão do Poder Legislativo e manteve a interação entre o Executivo e as Comissões Legislativas, inclusive a competências das Comissões de acompanhar, junto ao Governo, os atos de regulamentação, velando por sua completa adequação (art. 17, § $1^{\circ}$, IV) (BRASIL, 1987a, p. 7-19.

Portanto, três competências exclusivas do Congresso Nacional foram previstas pelo Anteprojeto saído da Comissão da Organização dos Poderes e Sistema de Governo que se complementavam: a de fiscalizar e controlar, conjuntamente ou através de qualquer das Casas, os atos do Executivo, inclusive da administração indireta; a de sustar os atos normativos do Poder Executivo que exorbitem do poder regulamentar ou dos limites de delegação legislativa; e a de regulamentar as leis, quando da omissão do Executivo. Ao mesmo tempo, se previa a competência das Comissões Legislativas de acompanhar, junto ao Governo, os atos de regulamentação, velando por sua completa adequação.

\section{O PROJETO DA COMISSÃO DE SISTEMATIZAÇÃO}

Na fase seguinte, o deputado constituinte Bernardo Cabral, relator da Comissão de Sistematização, incorporou a previsão da competência exclusiva do Congresso Nacional para sustar os atos normativos do Poder Executivo que exorbitem do poder regulamentar ou dos limites de delegação legislativa, nos mesmos termos em que prevista no Anteprojeto da Comissão da Organização dos Poderes e Sistema de Governo, tanto ao Anteprojeto de Constituição (art. 99, XII) como posteriormente ao Projeto de Constituição (art. 100, XII), ao Primeiro Substitutivo do Relator (art. 77, XIII), ao Segundo Substitutivo do Relator (art. 55, XII) e ao Substitutivo às emendas de Plenário aprovado pela Comissão de Sistematização (art. 55, XII) (BRASIL, 1987e, p. 17; BRASIL, 1987g, p. 17; BRASIL, 1987i, p. 26; BRASIL, 1987j, p. 41; BRASIL, 1987h, p. 27). Após a votação na Comissão de Sistematização, a competência exclusiva do Congresso Nacional para sustar os atos normativos do Poder Executivo que exorbitem do poder regulamentar ou dos limites de delegação legislativa passou a figurar no art. 59, XI, do Projeto de Constituição submetido ao Plenário para votação em primeiro turno (BRASIL, 1987f, p. 36). 
Em todas essas fases o Relator também manteve a competência privativa do Congresso Nacional para fiscalizar e controlar, conjuntamente ou através de qualquer das Casas, os atos do Executivo, inclusive da administração indireta. A partir do Primeiro Substitutivo, em que o papel das Comissões Legislativas foi sensivelmente restringido, o Relator da Comissão de Sistematização excluiu a competência dessas Comissões para acompanhar, junto ao Governo, os atos de regulamentação e velar por sua completa adequação. Por sua vez, o Relator da Comissão de Sistematização também excluiu, em seu Segundo Substitutivo, a competência exclusiva do Congresso Nacional para regulamentar as leis, quando da omissão do Executivo. O Relator manteve os demais mecanismos para o exercício do controle parlamentar no projeto de Constituição, com modificações pontuais, especialmente para adequar à revisão do papel mais estrito desenhado para as Comissões Legislativas. Por sua vez, além das prerrogativas do Legislativo, o Relator manteve no projeto de Constituição apresentado para votação em Plenário o sistema parlamentarista misto, com seus instrumentos institucionais de corresponsabilidade pelo Governo entre o Executivo e o Legislativo.

\section{A REBELIÃO DO CENTRÃO}

Após a votação dos Substitutivos do Relator na Comissão de Sistematização o Projeto de Constituição, em 24 de novembro de 1987, estava pronto para votação em Plenário. Segundo o Regimento Interno da ANC, a votação se daria em bloco por títulos ou capítulos e o Projeto só poderia sofrer emendas ou destaques sobre artigos específicos (art. 23 e art. 27 da Resolução no 2, de 1987), cuja aprovação requeria o voto da maioria absoluta dos membros da ANC, conforme a regra da EC no 26/85. Nesse momento, um movimento liderado por integrantes de partidos conservadores canalizou a insatisfação na condução dos trabalhos de vários constituintes e propôs a reforma do Regimento Interno.

A centralização dos trabalhos nas Comissões e Subcomissões, que produziu a ociosidade e a falta de visibilidade dos constituintes que não as integravam, o grande poder conferido aos integrantes das Comissões, em especial aos Relatores, as dificuldades para apresentação de emendas e substitutivos pelos demais constituintes e a agenda progressista que se desenhava no Projeto de Constituição estão na origem do movimento de reforma do Regimento Interno. Esse grupo reformista, que apregoava a necessidade de prevalência da vontade da maioria do Plenário, ficou conhecido como "Centrão", apontam Bonavides e Andrade (2008, p. 464-466) e Souza Neto e Sarmento (2013, p. 166-167). Ressalta Lopes que o Centrão "Era uma mobilização justificada pela frustração da participação individual dos constituintes durante a última fase da elaboração constitucional (a sistematização), antes do Plenário" (LOPES, 2008, p. 115).

Em 6 de janeiro de 1988, foi publicada a Resolução no 3, alterando o Regimento Interno (BRASIL, 1988j). A reforma previu a possibilidade de substitutivos e emendas coletivas pela maioria absoluta dos membros da ANC para títulos inteiros do Projeto de Constituição, com automática preferência de votação sobre o Projeto da Comissão de Sistematização, desde que apresentadas no prazo de sete dias da publicação e distribuição do Projeto de Constituição; emendas individuais para artigos, parágrafos, incisos ou alíneas do Projeto, limitado a quatro por constituinte; e requerimento de destaque para votação em separado, limitados a 6 por constituinte, a incidir, no todo ou em parte, sobre o texto de emenda individual ou popular, substitutivo ou dispositivo do Projeto de Constituição (art. $1^{\circ}$, art. $3^{\circ}$ e art. $4^{\circ}$, todos da Resolução $n^{\circ} 3$, de 1988).

A reforma do Regimento Interno inverteu o ônus da maioria. Antes, era o projeto da Comissão de Sistematização que seria votado com preferência, de maneira que sua aprovação por maioria absoluta, com ressalva das emendas não prejudicadas e dos destaques, exigiria que qualquer mudança ao projeto tivesse de angariar 280 votos. Com a nova regra, a preferência de votação passou para as emendas coletivas substitutivas ao projeto originário subscritas pela maioria absoluta dos membros da ANC. Assim, se o Substitutivo fosse aprovado pela maioria absoluta, 
com a ressalva dos destaques e emendas não prejudicadas, a manutenção de qualquer das previsões originárias do projeto da Comissão de Sistematização precisaria obter a aprovação de 280 votos, como anota Oliveira (1993, p. 13).

O controle da agenda de votação era uma grande vantagem para o Centrão, uma vez que, em uma assembleia de votantes, a ordem das alternativas pode influenciar diretamente no resultado, como destaca Dahl (2012, p. 230). Em tese, é mais fácil aprovar um projeto em bloco, com a ressalva dos pontos de discordância, do que angariar a maioria necessária para derrubar cada ponto divergente em separado. Na votação em bloco, os votos contrários se diluem, uma vez que a tendência é que a maioria concorde com o projeto ao menos em parte. Já na votação em separado a divergência precisa formar a maioria (no caso, absoluta).

A votação, conforme definida na reforma do Regimento Interno, seguiria a ordem crescente dos Capítulos, Seções, Subseções e seus respectivos artigos, não sendo admitido requerimento de preferência de um sobre o outro. Votar-se-ia primeiro os capítulos do respectivo Título, seguido dos destaques e sucessivamente dos grupos de emendas, cuja aprovação ou rejeição prejudicariam as proposições de mérito conexa (art. $9^{\circ}$ da Resolução no 3 , de 1988).

O Centrão apresentou as seguintes Emendas substitutivas ao Projeto de Constituição da Comissão de Sistematização, que foram recebidas: 2P02036-4, substitutiva ao preâmbulo; 2P02037-2, substitutiva ao Título dos Princípios Fundamentais; 2P02038-1, substitutiva ao Título dos Direitos e Garantias Fundamentais; 2P02039-9, substitutiva do Título da Organização do Estado; 2P02040-2, substitutiva dos capítulos I, IV e V do Título sobre a Organização dos Poderes e Sistema de Governo; 2P02041-1, substitutiva ao Título da Defesa do Estado e das Instituições Democráticas; 2P02042-9, substitutiva ao Título da Tributação e do Orçamento; 2P01043-1, substitutiva ao Título da Ordem Econômica e Financeira; 2P02044-0, substitutiva ao Título da Ordem Social; 2P020045-8, substitutivo ao Ato das Disposições Constitucionais Gerais e Transitórias (BRASIL, 19881, p. 771-818).

Um dos substitutivos apresentado pelo Centrão foi a Emenda 2P02040-2, encabeçada pelo Deputado constituinte Eraldo Tinoco, do PFL da Bahia, e assinada por 286 constituintes, substitutiva aos capítulos sobre o Poder Legislativo, sobre o Poder Judiciário e sobre as Funções Essenciais à Justiça do Título da Organização dos Poderes e Sistema de Governo (BRASIL, 19881, p. 785-795). A Emenda do Centrão sobre a organização dos Poderes, portanto, não tratava do Poder Executivo, em função da ausência de consenso no grupo sobre o Sistema de Governo. A defesa da permanência do presidencialismo, em oposição ao parlamentarismo previsto no Projeto de Constituição, angariava adeptos tanto no Centrão quanto em partidos progressistas, recorda Pilatti (2016, p. 250-251).

A Emenda apresentada pelo Centrão não alterava substancialmente o Título IV do Projeto de Constituição da Comissão de Sistematização, que era mantido em linhas gerais, conforme destacado pela própria justificativa da Emenda. Uma vez que o grupo não obteve o consenso sobre o sistema de governo, foram mantidas tanto as prerrogativas do Legislativo como os mecanismos institucionais de funcionamento do sistema parlamentarista, apenas com modificações pontuais.

No que importa diretamente ao controle congressual sobre os atos normativos do Executivo, a Emenda do Centrão mantinha a previsão da competência exclusiva do Congresso Nacional para fiscalizar e controlar, conjuntamente, ou por qualquer das Casas, os atos do Poder Executivo, inclusive os da administração indireta, mas excluía a previsão da competência para sustar os atos normativos do Poder Executivo que exorbitem do poder regulamentar ou dos limites de delegação legislativa. No entanto, a emenda incluía uma nova competência exclusiva do Congresso Nacional: a de zelar pela preservação de sua competência legislativa em face da atribuição normativa dos outros poderes. Quanto às Comissões Legislativas, a Emenda do Centrão mantinha o seu papel mais restrito, tal que havia saído da Comissão de Sistematização, não prevendo a competência para acompanhar os atos de regulamentação junto ao Executivo. 
Assim, se por um lado o Substitutivo deixava o controle congressual em termos mais vagos, sem detalhar o mecanismo de sua efetivação, por não mais prever a possibilidade de que os atos exorbitantes fossem sustados pelo Congresso Nacional, por outro lado previa que esse controle se daria sobre os atos normativos dos demais Poderes.

\section{A VOTAÇÃO EM PRIMEIRO TURNO}

A Emenda do Centrão sobre a organização dos Poderes foi posta em votação em primeiro turno na 225 a Sessão da ANC, em 15 de março de 1988, obtendo o seguinte resultado: SIM: 359; NÃO: 81; ABSTENÇÃO: 6 (TOTAL 446) (BRASIL, 1988c, p. 8466-8474).

Logo após a aprovação da Emenda do Centrão, a ANC passou a examinar os destaques para votação em separado. O inciso XI do art. 59 do Projeto de Constituição, que previa a competência exclusiva do Congresso Nacional para sustar os atos normativos do Poder Executivo que exorbitem do poder regulamentar ou dos limites de delegação legislativa, foi objeto de 3 destaques para votação em separado, requeridos pelo deputado constituinte Victor Fontana, pelo senador constituinte Fernando Henrique Cardoso (PMDB de São Paulo) e pelo deputado constituinte Plínio Arruda Sampaio (PT de São Paulo) (BRASIL, 1988q, p. 4).

O deputado constituinte Plínio Arruda Sampaio defendeu em Plenário a aprovação do inciso previsto no Projeto de Constituição da Comissão de Sistematização, para inclui-lo no rol das competências privativas do Congresso Nacional da Emenda do Centrão, nos seguintes termos:

O SR. PLÍNIO ARRUDA SAMPAIO (PT-SP. Sem revisão do orador.) - Sr. Presidente, podemos ser rápidos, porque a matéria parece-me pacífica. Está na idéia de restabelecer, nesta Casa, prerrogativas que sempre foram suas, que fortalecem o Poder Legislativo, ao restabelecer o controle democrático sobre o Poder Executivo.

$\mathrm{Na}$ verdade, a emenda que agora foi deslocada ${ }^{2}$ cuidava desse aspecto em uma de suas partes, porque dizia, na parte final, que era competência do Senado Federal suspender, total ou parcialmente, a vigência de atos normativos da administração pública. Esta matéria está contida nos dois destaques de autoria do Constituinte Fernando Henrique Cardoso e no meu, que visam, única e exclusivamente, a restabelecer o texto da Comissão de Sistematização.

O que queremos nós? Queremos que esta Casa possa, soberana e livremente, sustar atos normativos do Poder Executivo que exorbitem do seu poder regulamentar. (Palmas.) Fazemos uma lei, o Executivo a regulamenta, sustamos o ato que exorbite desse poder. Damos ao Executivo uma delegação legislativa e retemos o poder de sustar qualquer ato que vá além daquilo que se delegou. É só o que tenho a dizer, e tenho certeza da sua aprovação. (Palmas.) (BRASIL, 1988c, p. 8503)

O Destaque do deputado constituinte Plínio Arruda Sampaio, posto em votação, obteve o seguinte resultado: SIM: 356; NÃO: 7; ABSTENÇÃO: 12 (TOTAL 375) (BRASIL, 1988c, p. 8503). Vê-se, portanto, que o destaque para manter a competência do Congresso Nacional de sustar os atos do Poder Executivo exorbitantes do poder regulamentar ou dos limites da delegação legislativa originalmente prevista no Projeto de Constituição da Comissão de Sistematização foi aprovado com apenas 3 votos a menos que a Emenda do Centrão.

Já o destaque do deputado constituinte Victor Fontana dizia respeito à sua Emenda individual 2P00652-3, que pretendia deslocar a competência de controle dos atos normativos do Executivo do Congresso Nacional para o Senado, aglutinando-a à competência para suspender a execução de lei declarada inconstitucional pelo Supremo Tribunal Federal, além de explicitar a possibilidade de suspensão parcial do ato normativo impugnado, restaurando os termos da sua proposta original ("suspender, total ou parcialmente, a vigência de atos normativos da Administração Pública Federal, direta ou indireta, que exorbitem do poder de regulamentar ou dos

${ }^{2}$ Referência à Emenda individual 2P00652-3 do deputado constituinte Victor Fontana, a seguir analisada. Revista de Direito Brasileira | São Paulo, SP | v. 21 | n. 8 | p. 43-61 |Set./Dez. 2018 
limites da delegação legislativa"). Na justificativa da Emenda, o Deputado constituinte Victor Fontana defendeu o deslocamento da competência para o Senado para garantir a eficácia do instituto, uma vez que rever textos regulamentares pelo Congresso seria mais difícil do que votar a alteração da lei descumprida ou agredida. A emenda recebeu Parecer contrário do Relator, sob o argumento de que a competência não poderia figurar no mesmo dispositivo que prevê a suspensão, pelo Senado, de lei declarada inconstitucional por decisão definitiva do Supremo Tribunal Federal, uma vez que são figuras jurídicas distintas, que a técnica legislativa recomenda sejam tratadas em instantes inconfundíveis. Outro argumento contrário à proposta de deslocar a competência para o Senado, apresentado em Plenário pelo senador constituinte José Fogaça, do PMDB do Rio Grande do Sul, foi que a autorização para a edição de Leis Delegadas é dada pelo Congresso Nacional, de maneira que a sustação do ato que exorbite a delegação deve ser feita igualmente pelo Congresso Nacional. A Emenda do deputado constituinte Victor Fontana foi declarada prejudicada pelo Presidente da ANC, em razão da anterior aprovação do destaque para votação em separado do deputado constituinte Plínio de Arruda Sampaio, que manteve a competência em questão como privativa do Congresso Nacional (BRASIL, 1988c, p. 8502; BRASIL, 1988d, p. 8558-8559; BRASIL, 1988k, p. 249; BRASIL, 2018b).

Ainda durante o primeiro turno, na votação do capítulo do Poder Legislativo, na $227^{\mathrm{a}}$ sessão, no dia 17 de março de 1988, a ANC aprovou a fusão da Emenda n 2P00107/6 e do Destaque $n^{\circ} 2.055$, respectivamente do deputado constituinte Henrique Córdova, do PDS de Santa Catarina e do deputado constituinte Fernando Lyra, do PMDB de Pernambuco, como Emenda Substitutiva aos $\S \S 1^{\circ}$ e $2^{\circ}$ do art. 70 do Substitutivo-Emenda 2P02040 (a Emenda do Centrão), para dispor sobre as competências das Comissões do Congresso Nacional e de suas Casas. O texto resultante da fusão, aprovado por 334 votos (67 votos contrários e 17 abstenções), restabelecia a maior atuação das Comissões para dinamizar os trabalhos legislativos e resgatava a competência das Comissões para acompanhar, junto ao governo, os atos de regulamentação, velando por sua completa adequação (BRASIL, 1988e, p. 8620-8624).

\section{A EMENDA PRESIDENCIALISTA}

Desde a votação da Emenda do Centrão, o grupo presidencialista, pela voz do deputado constituinte Maurílio Ferreira Lima, do PMDB de Pernambuco, deixou claro que o voto em favor do capítulo sobre o Poder Legislativo, tal qual previsto no Substitutivo, não representava apoio às medidas parlamentaristas, uma vez que a questão sobre o sistema de governo seria decidia ao se votar o capítulo sobre o Poder Executivo. O Presidente da ANC assegurou que a eventual aprovação do sistema presidencialista importaria nas adaptações no capítulo do Poder Legislativo, uma vez que "não pode haver um sistema legislativo parlamentarista com um sistema de governo presidencialista" (BRASIL, 1988c, p. 8470).

Ao momento da votação do capítulo do Poder Executivo, a Emenda Coletiva no 2P018301, encabeçada pelo senador constituinte Humberto Lucena, do PMDB da Paraíba, à época Presidente do Senado Federal, e assinada por 345 parlamentares constituintes, que pretendia manter o regime presidencialista na nova Constituição, teve preferência sobre o capítulo respectivo previsto no Projeto de Constituição da Comissão de Sistematização. O texto da Emenda Humberto Lucena foi apresentado em Plenário resultado da fusão com a Emenda 2P00093-2, de autoria do deputado constituinte Maurílio Ferreira Lima, prevendo a adaptação das normas do capítulo do Poder Legislativo, excluindo os mecanismos de funcionamento do sistema parlamentarista e adequando a redação para excluir as referências à figura do Primeiro Ministro. No entanto, no que toca às prerrogativas do Legislativo, a Emenda não previa qualquer alteração, inclusive quanto à competência do Congresso para sustar os atos normativos do Poder Executivo que exorbitem do poder regulamentar ou dos limites de delegação legislativa. 
Por outro lado, a Emenda presidencialista reforçava as prerrogativas do Legislativo, prevendo instrumentos de colorido parlamentarista, como a moção de censura a Ministro de Estado, de iniciativa de um terço da Câmara dos deputados e aprovado por dois terços dos seus membros, que implicaria na exoneração do Ministro a que se referir; e a possibilidade de aprovação, pelo voto de dois terços dos membros da Câmara dos deputados ou ao Senado Federal, de Resolução de discordância de depoimento de Ministro convocado a prestar esclarecimento (BRASIL, 1988f, p. 8733-8736).

O deputado constituinte Bernardo Cabral, contrário à Emenda presidencialista, na condição de relator geral do Projeto de Constituição na Assembleia Nacional Constituinte, argumentou que as normas sobre o Poder Legislativo, inclusive a competência de sustar atos normativos do Poder Executivo, poderiam se tornar incongruentes com a mudança para o sistema presidencialista. Alertou o relator: "no artigo que estabelece a competência do Congresso Nacional, inclui-se a possibilidade de sustar atos normativos do Poder Executivo, o que seria mais palatável a um regime parlamentarista, mas com enormes riscos num regime presidencialista" (BRASIL, 1988n, p. 33-34). O relator da Constituinte, no entanto, estendia o mesmo argumento aos institutos da medida provisória e do veto presidencial.

A Emenda Presidencialista foi posta em votação, em primeiro turno, na 230 a Sessão da ANC, no dia 22 de março de 1988, obtendo o seguinte resultado: SIM: 344; NÃO: 212; ABSTENÇÃO: 3 (TOTAL 559) (BRASIL, 1988f, 8747-8749). Foi a primeira votação que contou com a participação de todos os congressistas constituintes, como ressaltam Bonavides e Andrade (2008, p. 468).

\section{O SEGUNDO TURNO DE VOTAÇÕES E A REDAÇÃO FINAL}

Após o primeiro turno de votação, o projeto de Constituição que foi submetido à discussão e votação em segundo turno manteve, em fidelidade às deliberações do Plenário, a previsão da competência exclusiva do Congresso Nacional para: (a) sustar os atos normativos do Poder Executivo que exorbitem do poder regulamentar ou dos limites de delegação legislativa. $(b)$ fiscalizar e controlar, diretamente, ou por qualquer de suas Casas, os atos do Poder Executivo, inclusive os da administração indireta; e $(c)$ zelar pela preservação de sua competência legislativa em face da atribuição normativa dos outros Poderes, nos termos do art. 50, VI, X e XI do projeto. O Projeto manteve, ainda, a competência das Comissões Legislativas para acompanhar, junto ao governo, os atos de regulamentação, velando por sua completa adequação, nos termos do art. 60, § $2^{\circ}$, IV (BRASIL, 1988o, p. 52).

A última tentativa de retirar do texto constitucional a competência do Congresso Nacional de sustar os atos exorbitantes do Poder Executivo se deu na votação em segundo turno. Nessa fase dos trabalhos, que permitia apenas emendas supressivas, o deputado constituinte Érico Pegoraro, do PFL do Rio Grande do Sul, apresentou a Emenda 01277, de 11 de julho de 1988, com o objetivo de suprimir a expressão "do poder regulamentar" da norma então constante do art. 50, VI do Projeto de Constituição. Na justificativa da Emenda apresentada, o deputado constituinte sustentou que a expressão a ser suprimida "conflita com o art. 102 e demais disposições que atribuem ao Poder Judiciário competência para apreciar a constitucionalidade e legalidade dos atos do Poder Público" (BRASIL, 1988p, p. 155). O relator geral da Constituinte, deputado constituinte Bernardo Cabral, em seu Parecer de rejeição da emenda, consignou:

É proposta, com a Emenda, a supressão, no item VI do art. 50, da expressão "do poder regulamentar".

O dispositivo sob proposta de supressão parcial prevê que se insere na competência do

Congresso Nacional "sustar os atos normativos do Poder Executivo que exorbitem do poder regulamentar ou dos limites de delegação legislativa". 


\begin{abstract}
Entende o nobre Autor da Emenda que o dispositivo, se mantido como está, representaria conflito de competência deferida ao Poder Judiciário, a quem cabe "apreciar a constitucionalidade e a legalidade dos atos do Poder Público".

A nosso entender o fato de caber ao Poder Judiciário apreciar a constitucionalidade e a legalidade dos atos do Poder Público não impede que o Congresso Nacional, quando se trate de lei por ele aprovada ou de delegação por ele concedida, suste a exigibilidade das normas regulamentares e da lei delegada quando entenda haver o Poder Executivo exorbitado no exercício da competência regulamentar ou delegada.

Pelas precedentes razões somos pela rejeição da Emenda. (BRASIL, 1988m, p. 125)
\end{abstract}

Na 322 ${ }^{\text {a }}$ Sessão da ANC, no dia 23 de agosto de 1988, o Deputado constituinte Érico Pegoraro, atendendo a apelo do Relator Bernardo Cabral, retirou em Plenário a Emenda 01277 (BRASIL, 1988h, p. 12944).

Também na $322^{a}$ Sessão, a ANC aprovou no segundo turno de votações a supressão da moção de censura a Ministro de Estado e a resolução de discordância ao depoimento e às respostas de Ministro de Estado às interpelações dos parlamentares (BRASIL, 1988h, p. 12945-1294812952); e na $323^{\text {a }}$ Sessão, no dia 24 de agosto de 1988, a ANC aprovou a supressão da competência das Comissões Legislativas para acompanhar, junto ao Governo os atos de regulamentação, velando por sua completa adequação (BRASIL, 1988i, p. 13010-13015). Sobre essas alterações, anota Lopes que mesmo os líderes parlamentaristas apoiaram "a iniciativa de membros presidencialistas da Assembléia (incluindo constituintes que, desde antes da definição do regime de governo, só aceitavam um presidencialismo puro), no sentido de expurgar o texto-base das incrustações que trazia de outro sistema" (LOPES, 2008, p. 168).

Após a votação em segundo turno, a redação final do projeto de Constituição consolidada pela Comissão de Redação, restaram três competências relacionadas ao controle parlamentar dos atos normativos do Poder Executivo: (a) sustar os atos normativos do Poder Executivo que exorbitem do poder regulamentar ou dos limites de delegação legislativa; $(b)$ fiscalizar e controlar, diretamente, ou por qualquer de suas Casas, os atos do Poder Executivo, incluídos os da administração indireta; e $(c)$ zelar pela preservação de sua competência legislativa em face da atribuição normativa dos outros Poderes (art. 49, V, X e XI) (BRASIL, 1988b, p. 37).

\title{
10 A TENTATIVA DE INTRODUÇÃO DO CONTROLE DE ATOS NORMATIVOS DO PODER JUDICIÁRIO
}

Embora não seja o objeto específico do presente estudo, que se concentra na análise do controle parlamentar sobre os atos normativos do Executivo, é oportuno observar que o deputado constituinte Lysâneas Maciel, do PDT do Rio de Janeiro, apresentou, ainda na fase das emendas de Plenário ao Anteprojeto da Comissão de Sistematização, antes da reforma do Regimento Interno, a Emenda ES29881-0, de 4 de setembro de 1987, que propunha a seguinte redação ao art. 77, XIII do Primeiro Substitutivo do Relator: "sustar os atos normativos do Executivo ou de natureza administrativa do Poder Judiciário que exorbitem do poder regulamentar ou dos limites de delegação legislativa" (BRASIL, 19871, p. 2200). A base de dados do Senado Federal sobre os trabalhos constituintes informa a existência de outra Emenda de teor parecido: a Emenda 19299, de 13 de agosto de 1987, do deputado constituinte Vivaldo Barbosa, do PDT do Rio de Janeiro, que incluía na competência exclusiva do Congresso a sustação também de atos do Poder Judiciário exorbitantes do poder regulamentar ou dos limites da delegação legislativa (BRASIL, 2018c). ${ }^{3}$ Essas emendas não foram acolhidas pela Comissão de Sistematização. Por sua vez, após a votação do segundo turno, na fase de Emendas de redação, o deputado constituinte Brandão Monteiro, do PDT do Rio de Janeiro, apresentou a Emenda 00322, de 16 de setembro de 1988, que igualmente

\footnotetext{
${ }^{3}$ Não se localizou, nos documentos digitalizados e disponíveis no sítio na internet da Câmara dos Deputados, a cópia relativa a essa Emenda.
}

Revista de Direito Brasileira | São Paulo, SP | v. 21 | n. 8 | p. 43-61 |Set./Dez. 2018 
não foi acolhida, agora pela Comissão de Redação, visando adequar a redação do art. 49, V para incluir a possibilidade de sustar atos também do Poder Judiciário exorbitantes do poder regulamentar ou dos limites da delegação legislativa. Eis a justificativa para a Emenda apresentada:

\begin{abstract}
Cuida-se de compatibilizar o dispositivo com a outorga constitucional da mesma competência regulamentar ao Poder Judiciário.

O Projeto Constitucional, no ensejo dos textos supra-legais últimos, do Brasil, concedem [sic] poder normativo aos Tribunais, promovendo norma excepcionadora da separação clássica dos Poderes e da decorrente indelegabilidade de funções do mesmo modo que conferiu ao Poder Executivo, também em regra tradicional no constitucionalismo pátrio, atribuição inovadora na ordem Jurídica, de mesmo teor.

Assim, quando se trata de tutelar à exorbitância desses potestades extra-funcionais conferidos ao Executivo, não se pode olvidar o Judiciário, sob pena de tornarem-se insindicáveis ao controle legislativo os atos regulamentares por ele praticados, o que desvirtuaria e amesquinharia o sistema introduzido. (BRASIL, 1988a, p. 49)
\end{abstract}

Vê-se, portanto, que a discussão sobre o controle congressual sobre os atos normativos do Poder Judiciário, exorbitantes do poder regulamentar ou da delegação legislativa, esteve presente nos trabalhos da ANC. Embora a proposta não tenha sido expressamente acolhida, essa possibilidade de controle estava alcançada pela previsão mais ampla introduzida pela Emenda do Centrão, ao estipular o dever do Congresso Nacional de zelar pela preservação de sua competência legislativa em face da atribuição normativa dos outros poderes. No entanto, a possibilidade de sustação pelo controle congressual foi expressamente prevista somente para os atos exorbitantes do Poder Executivo.

O Congresso Nacional já tentou exercer esse tipo de controle, por meio do Decreto Legislativo $\mathrm{n}^{\circ}$ 424, de 04 de dezembro de 2013, que sustou os efeitos da Resolução $\mathrm{n}^{\circ} 23.389$, de 9 de abril de 2013, expedida pelo Tribunal Superior Eleitoral, sob o argumento de que a norma sustada, ao alterar o número de representantes na Câmara dos Deputados e nas Assembleias Legislativas Estaduais, por critério de arredondamento, teria extrapolado os limites da delegação concedida pela Lei Complementar 78/2013. O referido Decreto Legislativo foi declarado inconstitucional, formal e materialmente, pelo Supremo Tribunal Federal, em 18/06/2014, ao julgar improcedente a Ação Declaratória de Constitucionalidade n ${ }^{\circ} 33-\mathrm{DF}$, em decisão conjunta com as Ações Diretas de Constitucionalidade no 4.947, 5.020 e 5.028. O Ministro Gilmar Mendes, Relator da $\mathrm{ADC} \mathrm{n}^{\circ}$ 33-DF, formulou o entendimento de que não é possível a edição de Decreto Legislativo para o controle de atos do Poder Judiciário, por conta da violação à separação de poderes. A esse argumento, agregou o entendimento de que o Decreto Legislativo não poderia alterar os termos da lei complementar, que outorgou atribuições ao Tribunal Superior Eleitoral, bem como que teria havido violação ao princípio da anterioridade eleitoral, previsto no art. 16 da Constituição, uma vez que o Decreto Legislativo foi editado há menos de um ano das eleições. O Tribunal acolheu, por unanimidade, o voto do Relator, ausente apenas a Ministra Cármen Lúcia.

\title{
11 ANÁLISE DOS TRABALHOS CONSTITUINTES
}

Finalizado esse levantamento dos dados históricos da tramitação dos trabalhos da ANC, pode-se alcançar algumas conclusões parciais sobre os trabalhos constituintes.

A forma de desenvolvimento dos trabalhos assumiu grande impacto sobre os resultados alcançados pela ANC, o que não foi diferente no caso da competência do Congresso de sustar os atos normativos do Poder executivo exorbitantes do poder regulamentar e dos limites da delegação legislativa. Nesse ponto, as variáveis que atuaram na configuração da competência em estudo foram a existência de subcomissões em separado para o Poder Legislativo e o Poder Executivo, a modificação das normas regimentais promovidas pelo Centrão às vésperas da votação do Projeto de Constituição, a forma de votação em Plenário, por capítulos e na ordem em que se apresentam 
no Título, com preferência dos Substitutivos oriundos das Emendas coletivas sobre o Projeto da Comissão de Sistematização e a indefinição do Centrão em relação ao tema do sistema de governo. O resultado dessa estrutura institucional, fortemente ditada pelas regras procedimentais, foi a relativa independência que a competência assumiu em relação ao projeto parlamentarista, no contexto da recuperação das prerrogativas do Poder Legislativo.

A competência exclusiva do Congresso Nacional de sustar atos normativos do Poder Executivo, oriunda de Emenda apresentada desde os trabalhos da Subcomissão do Poder Legislativo pelo deputado constituinte Victor Fontana, foi introduzida nos trabalhos constituintes em um contexto de recuperação das prerrogativas do Legislativo. A proposta, denominada por seu autor de "veto legislativo", tinha por base a preservação do princípio da legalidade.

A intenção originária de instituição do sistema parlamentarista de Governo pode ter impulsionado a valorização do Legislativo e a busca por reduzir a hipertrofia do Executivo, mas esses objetivos tinham força própria nos trabalhos da ANC.

A tentativa da Emenda do Centrão de substituir a competência para termos mais vagos não obteve sucesso. O resultado das votações do Substitutivo do Centrão e dos destaques para votação em separado foi que as duas previsões - a mais genérica da Emenda do Centrão (zelar pela preservação de sua competência legislativa em face da atribuição normativa dos outros Poderes) e a mais específica, resultado do Projeto de Constituição da Comissão de Sistematização (sustar os atos normativos do Poder Executivo que exorbitem do poder regulamentar ou dos limites de delegação legislativa) - foram incluídas no Texto constitucional (art. 49, V e XI da Constituição). Além disso, o resultado do primeiro turno de votações sobre o capítulo do Poder Legislativo reincorporou a competência das Comissões Legislativas de acompanhar, junto ao governo, os atos de regulamentação, velando por sua completa adequação, a qual foi excluída na votação do segundo turno.

A questão do sistema de governo foi apresentada somente na votação do capítulo sobre o Poder Executivo, quando já havia sido definido o perfil do Poder Legislativo. De toda forma, não é correto supor que o maior protagonismo do Legislativo no controle do Executivo decorre exclusivamente da premissa parlamentarista. Havia, na Constituinte, um propósito claro de reforço das prerrogativas institucionais do Legislativo. Lopes (2008, p. 226-228), ao analisar o processo constituinte brasileiro de 1987-1988, conclui que a introdução do sistema presidencialista não excluiu institutos híbridos - como a medida provisória, a lei delegada e outros mecanismos -, que, de alguma forma, aproximam os dois sistemas de Governo na formatação do modelo constitucional.

De fato, mesmo a Emenda presidencialista, que tinha por objetivo remover os mecanismos do sistema parlamentarista, assegurando a eleição do Presidente de forma direta em separado do Congresso, preservou as prerrogativas institucionais do Parlamento, inclusive quanto à fiscalização e o controle do Poder Executivo. Havia um aspecto de conciliação na proposta presidencialista originária, que ampliava as prerrogativas do Legislativo, por meio dos instrumentos da moção de censura e de resolução de discordância a Ministros de Estado, que só foram excluídas do texto na votação do segundo turno.

\section{CONCLUSÃO}

É preciso distinguir, nos trabalhos constituintes, os mecanismos de reestruturação das prerrogativas do Legislativo, em especial do controle e fiscalização dos atos do Poder Executivo, e os típicos instrumentos institucionais de funcionamento do sistema parlamentarista. $\mathrm{O}$ coração do sistema parlamentarista estava no papel da Câmara na aprovação da indicação do PrimeiroMinistro e a moção de desconfiança e o voto de confiança, por um lado, e na possibilidade de dissolução do Congresso, por outro. 
O projeto parlamentarista previa uma interação estreita entre o Executivo e as Comissões Legislativas, as quais teriam inclusive a competência de zelar pela regulamentação das Leis. Também é de forte característica parlamentarista a competência que se previa para o Congresso Nacional de regulamentar as leis, na omissão do Poder Executivo. Essas duas competências, no entanto, não eram um elemento essencial do sistema parlamentarista de Governo, tanto que já não mais subsistiam no Projeto de Constituição saído da Comissão de Sistematização. A competência das Comissões Legislativas de acompanhar a regulamentação das leis chegou a ser aprovada no primeiro turno de votações, sendo excluída no segundo.

Por outro lado, há uma série de prerrogativas do Poder Legislativo que não caracterizam o sistema de governo como parlamentarista, ainda que sua adoção possa ter se beneficiado do ambiente institucional da ANC. Assim, por exemplo, o poder impediente, pelo qual a Câmara dos Deputados poderia impedir, por meio de moção ao Presidente da República, que um cidadão continuasse a ocupar um determinado cargo no Poder Executivo, previsto no Anteprojeto da Subcomissão do Poder Legislativo, ou mesmo a moção de censura a Ministro, previsto no projeto originário da Emenda presidencialista, não eram mecanismos essenciais do sistema parlamentarista, devendo ser vistos como elementos do controle congressual sobre o Executivo, paralelo à competência do Senado para aprovar a indicação de nomes para o exercício de determinados cargos. Ainda que se tratem de competências bastante intrusivas ao Poder Executivo, seria imaginável a sua adoção mesmo em um sistema presidencialista. O mesmo se deve dizer sobre a competência para sustar atos normativos do Poder Executivo.

No calor dos debates constituintes, invocou-se o argumento da incongruência das prerrogativas do Legislativo, gestadas ainda no contexto do projeto parlamentarista, com o presidencialismo. O mesmo argumento, no entanto, foi utilizado para institutos como a medida provisória e o veto presidencial e poderia ter sido estendido para outros dispositivos constitucionais, como o que permite aos congressistas o exercício de cargos no Executivo, sem a perda do mandato (art. 56, I, da Constituição). A Emenda presidencialista operava grande reengenharia institucional, ao prever a figura da moção de desconfiança e a resolução de discordância a Ministro de Estado. Esse excesso de hibridismo, no entanto, foi afastado na votação do segundo turno.

Somente a idealização de um sistema presidencialista puro pode fundamentar o juízo de valor negativo sobre uma competência específica, como a prevista no art. 49, V, da Constituição, que integra o complexo sistema de pesos e contrapesos entre os Poderes.

$\mathrm{O}$ resultado do desenho institucional do sistema presidencialista que emergiu dos trabalhos da Assembleia Nacional Constituinte é fruto das circunstâncias concretas de elaboração do texto constitucional. Certamente a tradição constitucional brasileira, que remonta à primeira Constituição republicana de 1981, é responsável por moldar, ao longo dos anos, o presidencialismo brasileiro. Todavia, uma nova competência instituída no sistema, que amplia a forma de controle do Parlamento sobre o Executivo não é, em si, uma descontinuidade no regime presidencialista. Dessa forma, não é correto entender a competência do art. 49, V da Constituição como uma indevida reminiscência parlamentarista incompatível com a adoção do presidencialismo.

\section{REFERÊNCIAS}

BONAVIDES, Paulo; ANDRADE, Paes de. História Constitucional do Brasil. Brasília: OAB Editora, 2008.

BRASIL. Assembleia Nacional Constituinte. Comissão da Organização dos Poderes e Sistema de Governo. Anteprojeto da Comissão. v. 104. Brasília: Centro Gráfico do Senado Federal, jun. 1987a. 
BRASIL. Assembleia Nacional Constituinte. Comissão da Organização dos Poderes e Sistema de Governo. Subcomissão do Poder Legislativo. Anteprojeto do Relator da Subcomissão. v. 106. Brasília: Seção de Documentação Parlamentar, maio 1987b.

BRASIL. Assembleia Nacional Constituinte. Comissão da Organização dos Poderes e Sistema de Governo. Subcomissão do Poder Legislativo. Emendas ao Anteprojeto do Relator. v. 107. Brasília: Seção de Documentação Parlamentar, maio 1987c.

BRASIL. Assembleia Nacional Constituinte. Comissão da Organização dos Poderes e Sistema de Governo. Emendas oferecidas ao substitutivo. v. 102. Brasília: Centro Gráfico do Senado Federal, jun. 1987d.

BRASIL. Assembleia Nacional Constituinte. Comissão de Redação. Projeto de Constituição (C). Propostas exclusivamente de redação. v. 315. Brasília: Centro Gráfico do Senado Federal, set. 1988a.

BRASIL. Assembleia Nacional Constituinte. Comissão de Redação. Projeto de Constituição (C). Redação Final. v. 314. Brasília: Centro Gráfico do Senado Federal, set. 1988b.

BRASIL. Assembleia Nacional Constituinte. Comissão de Sistematização. Anteprojeto de Constituição. v. 219. Brasília: Centro Gráfico do Senado Federal, jun. 1987e.

BRASIL. Assembleia Nacional Constituinte. Comissão de Sistematização. Projeto de Constituição (A). v. 251. Brasília: Centro Gráfico do Senado Federal, nov. 1987f.

BRASIL. Assembleia Nacional Constituinte. Comissão de Sistematização. Projeto de Constituição. v. 226 Brasília: Centro Gráfico do Senado Federal, jul. 1987g.

BRASIL. Assembleia Nacional Constituinte. Comissão de Sistematização. Projeto de Constituição. Substitutivo da Comissão de Sistematização às emendas de plenário. v. 244. Brasília: Centro Gráfico do Senado Federal, out. 1987h.

BRASIL. Assembleia Nacional Constituinte. Comissão de Sistematização. Projeto de Constituição. Substitutivo do Relator (Primeiro). v. 235 Brasília: Centro Gráfico do Senado Federal, ago. 1987i.

BRASIL. Assembleia Nacional Constituinte. Comissão de Sistematização. Projeto de Constituição. Substitutivo do Relator (Segundo). v. 242. Brasília: Centro Gráfico do Senado Federal, set. 1987 j.

BRASIL. Assembleia Nacional Constituinte. Diário da Assembleia Nacional Constituinte, ano II, n. 206, 16 mar. 1988c.

BRASIL. Assembleia Nacional Constituinte. Diário da Assembleia Nacional Constituinte, ano II, n. 207, 17 mar. $1988 \mathrm{~d}$.

BRASIL. Assembleia Nacional Constituinte. Diário da Assembleia Nacional Constituinte. Ano II, n. 208, 18 mar. 1988e. 
BRASIL. Assembleia Nacional Constituinte. Diário da Assembleia Nacional Constituinte. Ano II, n. 211, 23 mar. 1988f.

BRASIL. Assembleia Nacional Constituinte. Diário da Assembleia Nacional Constituinte. Ano II, n. 255, 3 jun. 1988g.

BRASIL. Assembleia Nacional Constituinte. Diário da Assembleia Nacional Constituinte, ano II, n. 297, 24 ago. 1988h.

BRASIL. Assembleia Nacional Constituinte. Diário da Assembleia Nacional Constituinte, ano II, n. 298, 25 ago. 1988 i.

BRASIL. Assembleia Nacional Constituinte. Diário da Assembleia Nacional Constituinte. Resolução nº 2, de 1987. Ano I, n. 33, 25 mar. 1987k.

BRASIL. Assembleia Nacional Constituinte. Diário da Assembleia Nacional Constituinte. Resolução nº 3, de 1987. Ano II, n. 163, 6 jan. 1988j.

BRASIL. Assembleia Nacional Constituinte. Projeto de Constituição (A) - Emendas Oferecidas em Plenário. v. 254. Brasília: Centro Gráfico do Senado Federal, jan. 1988k.

BRASIL. Assembleia Nacional Constituinte. Projeto de Constituição (A) - Emendas Oferecidas em Plenário. v. 255. Brasília: Centro Gráfico do Senado Federal, jan. 19881.

BRASIL. Assembleia Nacional Constituinte. Projeto de Constituição (B). Parecer do Relator sobre as Emendas oferecidas em Plenário. v. 303. Brasília: Centro Gráfico do Senado Federal, jul. $1988 \mathrm{~m}$.

BRASIL. Assembleia Nacional Constituinte. Projeto de Constituição. Emendas oferecidas em plenário ao substitutivo do relator. v. 238. Brasília: Centro Gráfico do Senado Federal, set. 19871.

BRASIL. Assembleia Nacional Constituinte. Projeto de Constituição. Parecer do Relator sobre as Emendas oferecidas em Plenário. v. 260. Brasília: Centro Gráfico do Senado Federal, jan. 1988n.

BRASIL. Assembleia Nacional Constituinte. Projeto de Constituição. Redação para o segundo turno de discussão e votação. v. 299, suplemento 1. Brasília: Centro Gráfico do Senado Federal, jul. 1988 .

BRASIL. Assembleia Nacional Constituinte. Secretaria-Geral da Mesa. Projeto de Constituição (B). Emendas oferecidas em Plenário. v. 301. Brasília: Centro Gráfico do Senado Federal, jul. 1988p.

BRASIL. Assembleia Nacional Constituinte. Secretaria-Geral da Mesa. Título IV - Destaques Apresentados. v. 264. Brasília: Centro Gráfico do Senado Federal, fev. 1988q.

BRASIL. Câmara dos deputados. Constituintes. Biografia. Victor Fontana - PFL. Disponível em: <http://www2.camara.leg.br/atividadelegislativa/legislacao/Constituicoes_Brasileiras/constituicaocidada/constituintes/parlamentaresconstituintes/constituicao20anos_bioconstituintes?pk=106693 >. Acesso em: 12 jan. 2018a. 
BRASIL. Câmara dos deputados. Memória da Assembleia Nacional Constituinte. Disponível em: <http://www2.camara.leg.br/atividadelegislativa/legislacao/Constituicoes_Brasileiras/constituicao-

cidada/publicacoes/copy_of_index.html>. Acesso em: 24 dez. 2017a.

BRASIL. Senado Federal. Bases Históricas: Bases da Assembleia Nacional Constituinte 19871988. Disponível em: <http://www6g.senado.gov.br/apem/search>. Acesso em: 24 dez. 2017 b.

BRASIL. Senado Federal. Bases Históricas: Bases da Assembleia Nacional Constituinte 19871988. Emenda 00652: REJEITADA. Disponível em:

<http://www6g.senado.gov.br/apem/data/EMEN-S/67120.html>. Acesso em: 02 jan. 2018 b.

BRASIL. Senado Federal. Bases Históricas: Bases da Assembleia Nacional Constituinte 19871988. Emenda 19299: REJEITADA. Disponível em:

<http://www6g.senado.gov.br/apem/data/EMEN-M/49652.html>. Acesso em: 12 jan. 2018c.

CABRAL, J. Bernardo. O Poder Constituinte - fonte legítima - soberania - liberdade. Brasília: Câmara dos Deputados, fev. 1988.

CHIZZOTTI, Antonio. Pesquisa em Ciências Humanas e Sociais. 12. ed. São Paulo: Cortez, 2017.

CRESWELL, Johun W. Investigação qualitativa e projeto de pesquisa: escolhendo entre cinco abordagens. 3. ed. Porto Alegre: Penso, 2014.

DAHL, Robert A. A democracia e seus críticos. São Paulo: WMF Martins Fontes, 2012.

FERRAZ, Anna Cândida da Cunha. Comentários ao art. 49, V. In: CANOTILHO, J.J. GOMES; MENDES, Gilmar F.; SARLET, Ingo W.; STRECK, Lenio L. (Coords.). Comentários à Constituição do Brasil. São Paulo: Saraiva/Almedina, 2013, p. 1030-1031.

FERRAZ, Anna Cândida da Cunha. Conflito entre poderes: o poder congressual de sustar atos normativos do Poder Executivo. São Paulo: Editora Revista dos Tribunais, 1994.

GUIMARÃES, Ulisses. A Constituição Cidadã. Brasília: Diário da Assembleia Nacional Constituinte, jul. 1998, p. 12150-12151.

IENSUE, Geziela; SGARBOSSA, Luís Fernando. Revisibilidade judicial de decisões destituintes resultantes de responsabilidade política: uma análise a partir de diferentes contextos institucionais. Revista de Direito Brasileira. São Paulo, v. 14, n. 6, p. 264-285, maio/ago. 2016.

LOPES, Júlio Aurélio Vianna. A Carta da Democracia: o processo constituinte da ordem pública de 1988. Rio de Janeiro: Topbooks, 2008.

OLIVEIRA, Mauro Márcio. Fontes de informações sobre a Assembleia Nacional Constituinte de 1987: quais são, onde buscá-las e como usá-las. Brasília: Senado Federal, 1993.

PILATTI, Adriano. A Constituinte de 1987-1988: progressistas, conservadores, ordem econômica e regras do jogo. 2. ed. Rio de Janeiro: Lumen Juris, 2016. 
PILATTI, Adriano. A perspectiva institucionalista e a análise da dinâmica das decisões legislativas. Direito, Estado e Sociedade. Rio de Janeiro, v. 9, n. 29, p. 28- 48, jul/dez 2006.

POLETTI, Ronaldo. Constituições Brasileiras: 1934. Brasília: Senado Federal; Ministério da Ciência e tecnologia; Centro de Estudos Estratégicos, 2001.

SHUGART, Matthew Soberg; CAREY, John M. Presidents and Assemblies. Cambridge: Cambridge University Press, 1992.

SOUZA NETO, Cláudio Pereira de; SARMENTO, Daniel. Direito Constitucional: teoria, história e métodos de trabalho. 1. Reimpressão. Belo Horizonte: Fórum, 2013.

VALADÃO, Marcos Aurélio Pereira. Sustação de atos normativos do Poder Executivo pelo Congresso Nacional com base no artigo 49, inciso V, da Constituição de 1988. Revista de Informação Legislativa, Brasília, ano 38, n. 153, p. 287-301, jan./mar. 2002. 